\title{
Resistance to Root Galling Caused by the Powdery Scab Pathogen Spongospora subterranea in Potato
}

\author{
Nadav Nitzan, USDA-ARS, Prosser, WA 99350; Tom F. Cummings and Dennis A. Johnson, Washington State \\ University, Pullman, WA 99164; Jeff S. Miller, Miller Research, LCC., Rupert, ID 83350; Dallas L. Batchelor, \\ Weather Or Not, Pasco, WA 99301; Chris Olsen, L.J. Olsen, Inc., Othello, WA 99344; Richard A. Quick and \\ Charles R. Brown, USDA-ARS, Prosser, WA 99350
}

\begin{abstract}
Nitzan, N., Cummings, T. F., Johnson, D. A., Miller, J. S., Batchelor, D. L., Olsen, C., Quick, R. A., and Brown, C. R. 2008. Resistance to root galling caused by the powdery scab pathogen Spongospora subterranea in potato. Plant Dis. 92:1643-1649.

Potato (Solanum tuberosum) selections (clones and commercial cultivars) were examined for resistance to root galling, caused by the powdery scab pathogen Spongospora subterranea $\mathrm{f}$. sp. subterranea in seven field trials conducted between 2003 and 2007 in the states of Washington and Idaho. Four industry reference cultivars-Shepody, Russet Burbank, Russet Ranger, and Umatilla Russet-were used as susceptible standards. Every year, selections less susceptible than the standards were considered resistant and progressed to the next season. Selections that did not demonstrate resistance in at least two consecutive trials were discarded. Eight potato selections were more resistant to root galling than the susceptible standards in two or more trials: PA98NM38-1 was more resistant than the susceptible standards in 5 of 5 trials, PO94A009-10 in 4 of 5 trials, PA95B2-4 and PA98N5-2 in 3 of 5 trials, POR00HG5-1 in 2 of 5 trials, PO94A0097 in 3 of 4 trials, PO94A012-2 in 2 of 3 trials, and Summit Russet in 2 of 2 trials. POR00HG5-1 has Solanum hougasii in its ancestry, while the other selections have the Mexican wild species Solanum bulbocastanum and the commercial cultivar Summit Russet appearing in their ancestry. Summit Russet is the most plausible source of resistance.
\end{abstract}

Powdery scab of potato is caused by Spongospora subterranea f. sp. subterranea (S. subterranea) (11). Potato (Solanum tuberosum) cultivars that are susceptible to the disease demonstrate sponge-like galls on the roots and stolons and lesions on the tubers (11). Infected potato tubers and infested soils are means of disseminating the powdery scab pathogen, which can survive in soils for many years (15); it also can acquire and transmit the Potato moptop virus $(14,21)$.

$S$. subterranea is classified in the phylum Plasmodiophoromycota (1). The pathogen is an endoparasitic slime mold characterized by obligate parasitism, the formation of a plasmodium inside the roots and the tubers, biflagellated zoospores, infectious activity at temperatures between 10 and $20^{\circ} \mathrm{C}$ under wet conditions, and the formation of resting spores (cystosori or sporosori) commonly referred to as "spore balls" (11). The spore balls aggregate on the roots as galls, and in masses in the tuber lesions. The disease gets its name, powdery scab, from the appearance of the lesions.

Corresponding author: Charles Brown

E-mail: chuck.brown@ars.usda.gov

Accepted for publication 17 August 2008.

doi:10.1094/PDIS-92-12-1643

(C) 2008 The American Phytopathological Society
The life cycle of $S$. subterranea $(1,11)$ initiates with the spore balls that are the primary source of inoculum and can survive in the soil or on the surface of the tubers for many years. In the presence of a host and favorable environmental conditions, primary zoospores emerge from the spore balls to infect the root hairs. Following infection, a plasmodium develops within the root and cleaves into segments that develop into zoosporangia, releasing secondary zoospores. The secondary zoospores continue to infect roots and developing tubers. Eventually, root galls and tuber lesions are produced. It is suggested (11) that $S$. subterranea acts as a polycyclic pathogen and secondary zoospores are released from the root galls or from zoosporangia, increasing inoculum in the soil. Also, it is suggested (11) that during the life cycle of the pathogen, spore ball development in root galls or tuber lesions occurs at the same time as secondary zoospore infections.

Powdery scab is considered a blemish disease, impairing the appearance and reducing the quality of tubers $(8,11,27,28)$. On severely infected tubers, lesions may cover more than $75 \%$ of the surface, the epidermis can lose its flexibility, and cankers may develop (11). Infection of tubers tends to be superficial; however, lesions may be deep and destroy large proportions of the tubers (28). Heavily infected tubers may become deformed and unmarketable, and their growth during the season could be retarded, affecting yield weight $(6,11,25)$. Tubers infected with $S$. subterranea were reported to be more susceptible to potato pathogens such as Phytophthora infestans, P. erythroseptica, Fusarium spp., and Colletotrichum atramentarium (C. coccodes) $(5,6,10,11,24)$ than noninfected tubers.

The occurrence of powdery scab in the Columbia Basin of central Washington and north-central Oregon before 1981 was light and sporadic, but today it is a major concern for potato production (12). The disease occurs at high severities in many fields throughout the region (13), and processing cultivars such as Russet Burbank and Shepody are no longer commercially produced in fields where the pathogen's populations are high (Chris Olsen, unpublished data).

The variation in susceptibility to powdery scab involves both tubers and roots. The tubers of russet skin cultivars do not develop severe or noticeable tuber lesions as happens with tubers of white or red potatoes with smooth skin. On the other hand, roots of most, if not all, commercially successful cultivars demonstrate root galling to different levels (19). The majority of the potato cultivars grown in the states of Washington, Idaho, and Oregon are Russet Burbank, Russet Norkotah, and Ranger Russet (22). These cultivars are characterized by russet skin, and do not commonly demonstrate tuber lesions, but their roots are susceptible to powdery scab and become severely infected (12).

Lawrence and McKenzie (16) reported that infection of roots caused young plants to wilt and die. Root rot also was documented as a symptom of powdery scab (7), but it has not been widely reported. Falloon et al. (9) suggested that infection of potato roots by $S$. subterranea possibly disturbed the uptake of nutrient and water, and affected the translocation of photosynthetic sugars to tubers, possibly reducing tuber yields in weight. Field observations in the Columbia Basin of Washington State agreed with these reports indicating that potato plants infected with the pathogen developed necrotic and deformed roots. Damage to potato roots can influence the development of large (>280 g) tubers needed for processing, resulting in the reduction of useable potato yield (20). The potato industry of Washington State is 
concerned with damage to roots caused by powdery scab and its potential to reduce yield weight in tonnage and affect tuber size and quality.

The management of powdery scab through resistant potato cultivars may be the most reliable and sustainable technique if resistance is high enough and stable. Potatoes were documented to vary in response to powdery scab, and inherited resistance was considered to be polygenic $(2,11,19,26)$. The present study tested the hypothesis that resistance to root galling caused by the potato powdery scab pathogen $S$. subterranea is present in potato germplasm. The objectives were to identify resistance to root galling in potato germplasm that could be used as future commercial cultivars or as future breeding lines. The study was part of the Northwest Tri-State potato breeding program, which is a collaborative effort of the USDA/ARS, Oregon State University, Washington State University, University of Idaho, each state's potato commission, and industry representatives to develop potatoes with agronomic, horticultural, and pathological traits suitable and sought for by the potato industry in the Northwest region.

\section{MATERIALS AND METHODS}

Seven field trials were carried out between 2003 and 2007 in commercial fields with history and high populations of the potato powdery scab pathogen, S. subterranea. The fields were located near Moses Lake, WA, and Rexburg, ID. The potato seed-tubers were obtained from the Oregon State University, Central Oregon Experiment Station, located by Powell Butte, $\mathrm{OR}$; and from the USDA/ARS Potato Research Unit, located in Aberdeen, ID. The trials represented a randomized complete block design with a one-way treatment structure (potato selection), with 3 to 5 replicated blocks. The experimental plots were a single row of $86 \mathrm{~cm}$ wide $\times 114 \mathrm{~cm}$ long, planted with 5 tuber pieces ( 5 hills) at a distance of $23 \mathrm{~cm}$ from each other. The potato seed-tubers were cut into pieces of
$50 \mathrm{~g}$ on average. Then, the tuber-seed pieces were treated with Mancozeb (TOPS®MZ; Gustafson LCC, TX) by adding $5 \mathrm{ml}$ of the fungicide to 20 tuberseed pieces in a paper bag $(31 \times 18 \times 58$ $\mathrm{cm})$ and shaking well until the tuber seed pieces were fully covered with the fungicide. The tuber seed pieces were maintained in paper bags at $5^{\circ} \mathrm{C}$ until used. The trials were planted from late March to late May and were 2.5 to 4 months in duration (Table 1).

The trials were initiated in 2003 in order to establish a baseline and select susceptible standards. Twenty-one potato selections were tested in Moses Lake, and 24 in Rexburg (Table 1). These trials established Shepody, Russet Burbank, Russet Ranger, and Umatilla Russet as susceptible standards, and every year the potato selections tested were contrasted to these standards. Potato selections with significantly fewer root galls than the four standards were considered resistant to root galling and progressed to the next season's trial. Potato selections that did not demonstrate resistance in at least two consecutive trials were discarded. In 2004, 23 and 24 potato selections were tested for resistance to root galling in Washington and Idaho, respectively. In 2005, 2006, and 2007, 25, 36, and 23 potato selections were tested in Washington, respectively (Table 1).

Potato selections were evaluated for severity of root galls in the field. The plants, including the roots, were carefully pulled out of the ground, preventing root galls from falling off. The soil was brushed off the roots with the aid of a soft paint brush, and the number of root galls on the entire root system was visually evaluated and placed into category scale systems. Each category represented a range of an estimated number of root galls. In 2003, a 0 to 5 category scale was used, where: $0=$ no galls, $1=1$ to $10,2=11$ to $50,3=51$ to $100,4=101$ to 200 , and $5=>200$. In 2004 , in Washington, a 0 to 4 scale was used, where: $0=0,1=1$ to $25,2=26$ to $50,3=51$ to 100 , and $4=101$ to 150 ; and in Idaho, a 0 to 6 scale was used, where: 0 $=0,1=1$ to $25,2=26$ to $50,3=51$ to $100,4=101$ to $150,5=151$ to 200 , and 6 $=>200$. In 2005, a 0 to 7 scale was used, where: $0=0,1=1$ to $25,2=26$ to $50,3=$ 51 to $100,4=101$ to $150,5=151$ to 200 , $6=201$ to 250 , and $7=>250$. In 2006, the same 0 to 6 scale that was used in Idaho in 2004 was implemented. In 2007, the percentage of root surface covered with galls followed a 0 to 3 rating, where: $0=0,1=$ $<30 \%, 2=30$ to $60 \%$, and $3=>60 \%$. One to 25 plants were scored for severity of powdery scab galls on the roots (Table 1). The severity of root galls was represented as a weighted mean, calculated as follows: [the sum of (number of plants in category $\times$ category)]/(total number of scored plants).

The severity of root galls was recorded on a category basis as ordinal data using multiple scales in seven field trials over a 5-year period; therefore each year was analyzed separately. The Kruskal-Wallis analysis of variance by ranks (29) was carried out in SAS (SAS Institute, Cary, NC). The root galling values were ranked using Proc Rank in SAS, and ANOVA was carried out on the ranked values using the general linear models procedure (Proc GLM). All inferences were conducted at a $5 \%$ significance level. To determine resistance to powdery scab, the potato selections were contrasted to four susceptible standards-Shepody, Russet Ranger, Russet Burbank, and Umatilla Russet-using Fisher's least significant difference.

\section{RESULTS}

Fifty-seven potato selections (clones and cultivars) were tested for resistance to root galling at least once between 2004 and 2007. The potato selections were contrasted to the four industry standard cultivars, Shepody, Russet Burbank, Russet Ranger, and Umatilla Russet, which were regarded as susceptible to the disease. Umatilla Russet was more $(P<0.05)$ resistant to root galling than Shepody in 2 of 5 trials, and Russet Burbank and Rus-

Table 1. Year, location, planting and harvesting dates, number of selections tested, experimental design and evaluation scales of powdery scab resistance screening trials conducted between 2003 and 2007 in commercial potato fields in Moses Lake, WA and Rexburg, ID

\begin{tabular}{llllclc}
\hline Year & Location & Planting & Harvest & $\begin{array}{c}\text { Selections } \\
\text { tested }^{\mathbf{x}}\end{array}$ & $\begin{array}{c}\text { Root galls } \\
\text { Experimental design }^{\mathbf{y}}\end{array}$ & $\begin{array}{c}\text { scoring scale } \\
\mathbf{z}\end{array}$ \\
\hline 2003 & Moses Lake & 15 April & 27 August & 21 & RCBD, 5 replications/selection, 5 subsamples scored/replication & $0-5$ \\
2003 & Rexburg & 30 May & 14 August & 24 & RCBD, 3 replications/selection, 5 subsamples scored/replication \\
2004 & Moses Lake & 20 April & 8 September & 23 & RCBD, 4 replications/selection, 5 subsamples scored/replication & $0-5$ \\
2004 & Rexburg & 20 May & 13 September & 24 & RCBD, 4 replications/selection, 2-25 subsamples scored/replication & $0-4$ \\
2005 & Moses Lake & 26 April & 19 August & 25 & RCBD, 4 replications/selection, 1-5 subsamples scored/replication & $0-6$ \\
2006 & Moses Lake & 6 April & 11 August & 36 & RCBD, 4 replications/selection, 3 subsamples scored/replication & $0-7$ \\
2007 & Moses Lake & 30 March & 23 July & 23 & RCBD, 4 replications/selection, 5 subsamples scored/replication & $0-6$ \\
\hline
\end{tabular}

${ }^{\mathrm{x}}$ Selections $=$ potato clone or commercial cultivar.

${ }^{\mathrm{y}} \mathrm{RCBD}=$ randomized complete block design; replication = experimental plot; subsample $=$ plant.

${ }^{\mathrm{z}}$ In 2003, 2004, 2005, and 2006, severity of root galling was assessed on category scale system ranging from 0 to 4, 5, 6, or 7. Each category represented a range of an estimated number of root galls. In 2003, a 0 to 5 category scale was used, where: $0=$ no galls, $1=1$ to $10,2=11$ to $50,3=51$ to $100,4=101$ to 200 , and $5=>200$. In 2004, in Washington a 0 to 4 scale was used, where: $0=0,1=1$ to $25,2=26$ to $50,3=51$ to 100 , and $4=101$ to 150 . In 2004 , in Idaho a 0 to 6 scale was used, where: $0=0,1=1$ to $25,2=26$ to $50,3=51$ to $100,4=101$ to $150,5=151$ to 200 , and $6=>200$. In 2005 , a 0 to 7 scale was used, where: $0=0,1=1$ to $25,2=26$ to $50,3=51$ to $100,4=101$ to $150,5=151$ to $200,6=201$ to 250 , and $7=>250$. In 2006 , the scale was similar to the 2004 scale used in Idaho. In 2007, the category scale followed a 0 to 3 rating, where: $0=0,1=<30 \%, 2=30$ to $60 \%$, and $3=>60 \%$. 
set Ranger were more resistant than Shepody in 4 of 5 trials (Table 2). Russet Burbank was more resistant to root galling than Umatilla Russet in 3 of 5 trials, and Russet Ranger in 1 of 5 trials. Root gall severity did not differ between Russet Burbank and Russet Ranger in all 5 trials (Table 2).

In 2004, in Moses Lake, 7 of 23 potato selections were more $(P<0.05)$ resistant to root galling than the standard cultivars (Fig. 1); and in Rexburg, 6 of 24 potato selections were more resistant to root galling than the standard cultivars (Fig. 2). In 2005,17 of 25 potato selections were more resistant to root galling than the standard susceptible cultivars (Fig. 3). In 2006,10 of 36 potato selections were more resistant to root galling than the susceptible standards (Fig. 4). In 2007, 3 of 23 potato selections were more resistant to root galling than the four susceptible standards (Fig. 5).
Eight potato selections were more resistant to root galling than the four susceptible standard cultivars Shepody, Umatilla Russet, Russet Ranger, and Russet Burbank in two or more trials (Table 3). The potato selection PA98NM38-1 was more resistant than the susceptible standards in 5 of 5 trials. The potato selection PO94A009-10 was more resistant than the susceptible standards in 4 of 5 trials. The potato selections PA95B2-4 and PA98N5-2 were more resistant to root galling than the susceptible standards in 3 of 5 trials. The potato selection POR00HG5-1 was more resistant to root galling than the susceptible standards in 2 of 5 trials. The potato selection PO94A009-7 was more resistant to root galling than the susceptible standards in 3 of 4 trials. The potato selection PO94A012-2 was more resistant to root galling than the susceptible standards in 2 of 3 trials; and the potato selection Summit Russet was more resistant to root galling than the susceptible standards in 2 of 2 trials (Table 3 ).

\section{DISCUSSION}

The hypothesis that genetic resistance to root galling caused by the powdery scab pathogen $S$. subterranea is present in potato was tested from 2003 to 2007. Fiftyseven potato selections were tested at least once in the field under conditions that produced severe disease on four susceptible standard cultivars, Shepody, Russet Burbank, Russet Ranger, and Umatilla Russet. Eight potato selections had consistently fewer root galls than the susceptible standards in two or more field trials. These selections were PA98NM38-1, PA95B2-4, PA98N5-2, PO94A009-10, PO94A009-7, POR00HG5-1, PO94A012-2, and Summit Russet. These results supported the hypothesis that resistance to root galling caused by the powdery scab pathogen $S$. subterranea was present in potato. Potato

Table 2. Comparison of root galls severity among the four susceptible standard potato selections

\begin{tabular}{lccccc}
\hline & \multicolumn{5}{c}{ Root gall severity $^{\mathbf{z}}$} \\
\cline { 2 - 6 } Potato selection & 2004-ID & 2004-WA & 2005-WA & 2006-WA & 2007-WA \\
\hline Shepody & $1.4 \mathrm{a}$ & $2.7 \mathrm{a}$ & $5.8 \mathrm{a}$ & $3.3 \mathrm{a}$ & $1.8 \mathrm{a}$ \\
Umatilla Russet & $1.2 \mathrm{ab}$ & $1.3 \mathrm{~b}$ & $4.8 \mathrm{a}$ & $2.8 \mathrm{ab}$ & $1.2 \mathrm{~b}$ \\
Russet Ranger & $1.0 \mathrm{bc}$ & $1.7 \mathrm{~b}$ & $5.0 \mathrm{a}$ & $2.2 \mathrm{bc}$ & $0.4 \mathrm{c}$ \\
Russet Burbank & $0.7 \mathrm{c}$ & $1.3 \mathrm{~b}$ & $5.3 \mathrm{a}$ & $1.6 \mathrm{c}$ & $0.7 \mathrm{c}$ \\
\hline
\end{tabular}

${ }^{\mathrm{z}}$ The severity of root galling was assessed on a category scale that estimated the number of root galls. In 2003 a 0 to 5 category scale was used, where: $0=$ no galls, $1=1$ to $10,2=11$ to $50,3=51$ to $100,4=101$ to 200 , and $5=>200$. In 2004, in Washington a 0 to 4 scale was used, where: $0=0,1=1$ to 25,2 $=26$ to $50,3=51$ to 100 , and $4=101$ to 150 . In 2004, in Idaho a 0 to 6 scale was used, where: $0=0,1=1$ to $25,2=26$ to $50,3=51$ to $100,4=101$ to $150,5=151$ to 200 , and $6=>200$. In 2005 , a 0 to 7 scale was used, where: $0=0,1=1$ to $25,2=26$ to $50,3=51$ to $100,4=101$ to $150,5=151$ to 200,6 $=201$ to 250 , and $7=>250$. In 2006, the scale was similar to the 2004 scale used in Idaho. In 2007 the scale estimated the percent of root surface covered with galls. The category scale followed a $0-3$ rating, where: $0=0,1=<30 \%, 2=30$ to $60 \%$, and $3=>60 \%$. The Kruskal-Wallis analysis of variance by ranks (29) was carried out in SAS (SAS Institute, Cary, NC). The root galling values were ranked using Proc Rank in SAS, and ANOVA was carried out on the ranked values using the general linear models procedure (Proc GLM). All inferences were conducted at a 5\% significance level.

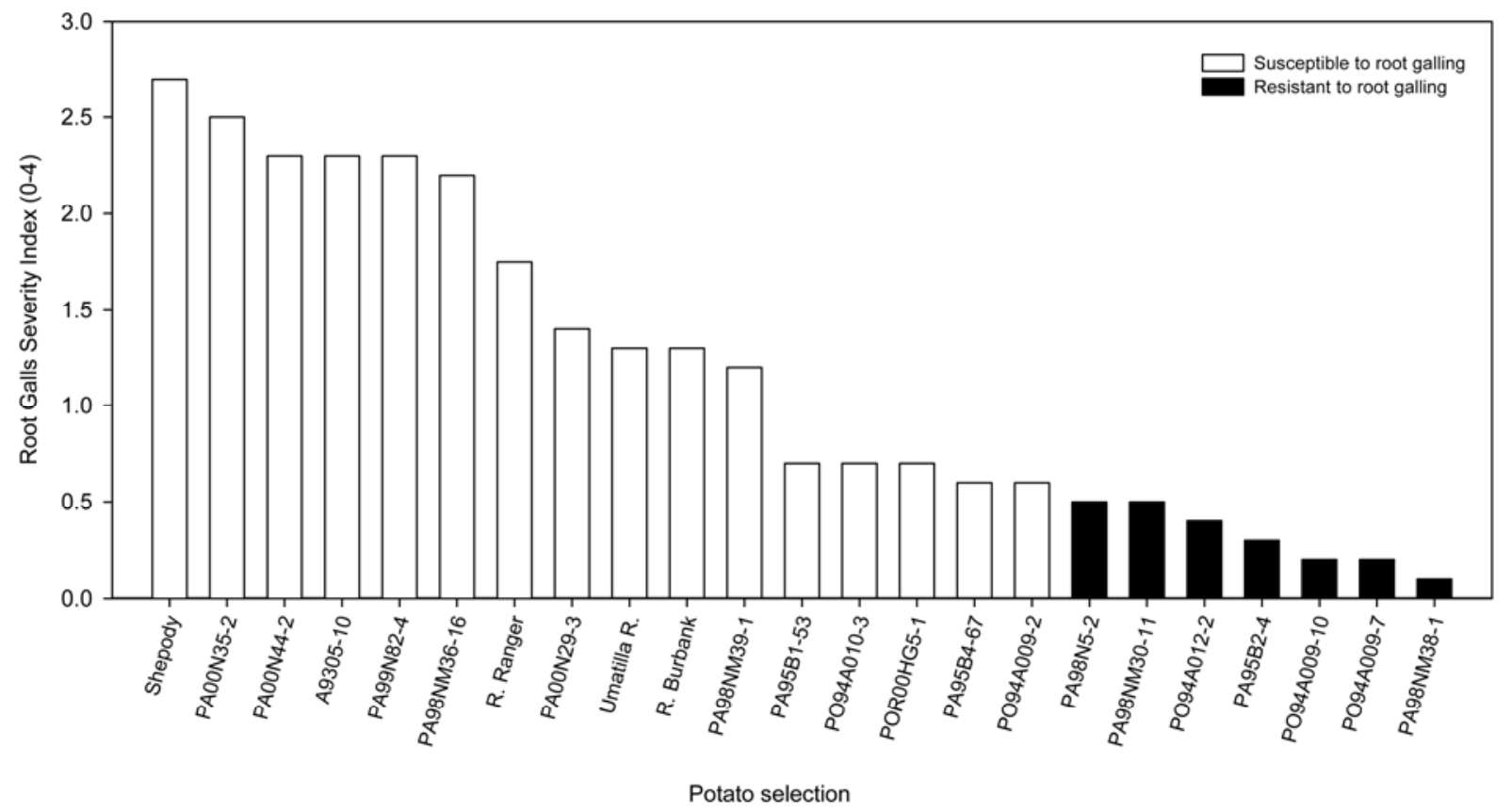

Fig. 1. The severity of galls on roots of potato selections tested for resistance to powdery scab in 2004 in a commercial field by Moses Lake, WA. The commercial cultivars Shepody, Russet Burbank, Russet Ranger, and Umatilla Russet were used as susceptible standards. Selections represented by black bars were significantly more $(P<0.05)$ resistant to root galling than the susceptible standards using Fisher's least significant difference $(\alpha=0.05)$. 
germplasm resistant to root galling that could be used as future commercial cultivars or as breeding lines were identified in this study.

In the literature, powdery scab is regarded as a tuber blemishing disease affecting tuber quality $(8,9,26,27)$. In the Pacific Northwest (PNW) of the United States, the majority of the potato production area is planted to long-season (4.5 to 6 months) russet skin cultivars used for processing (22). These cultivars are not severely affected by skin blemishes like nonrusset potatoes, but they are affected by root damage. In the Columbia Basin, $S$. subterranea infects potato roots early in the growing season while soil temperatures are cool due to cold nights; and irrigation water supplies the moisture needed for infection. Root galls usually appear 3 weeks after infection by the zoospores, which roughly correlates to 1.5 to 2 months after plant emergence (13). Little is documented about root galling of pow- dery scab, and even less of the association between root galling, root damage, and the effect on yield. No quantitative work has been published reporting the effects of galling on yield. Results from controlled field experiments are lacking because a satisfactory control (nondiseased) has not been developed for a comparison, and a disease-free control is needed to document an effect on yield. However, reports from the industry in Washington State indicated that certain processing cultivars with russet

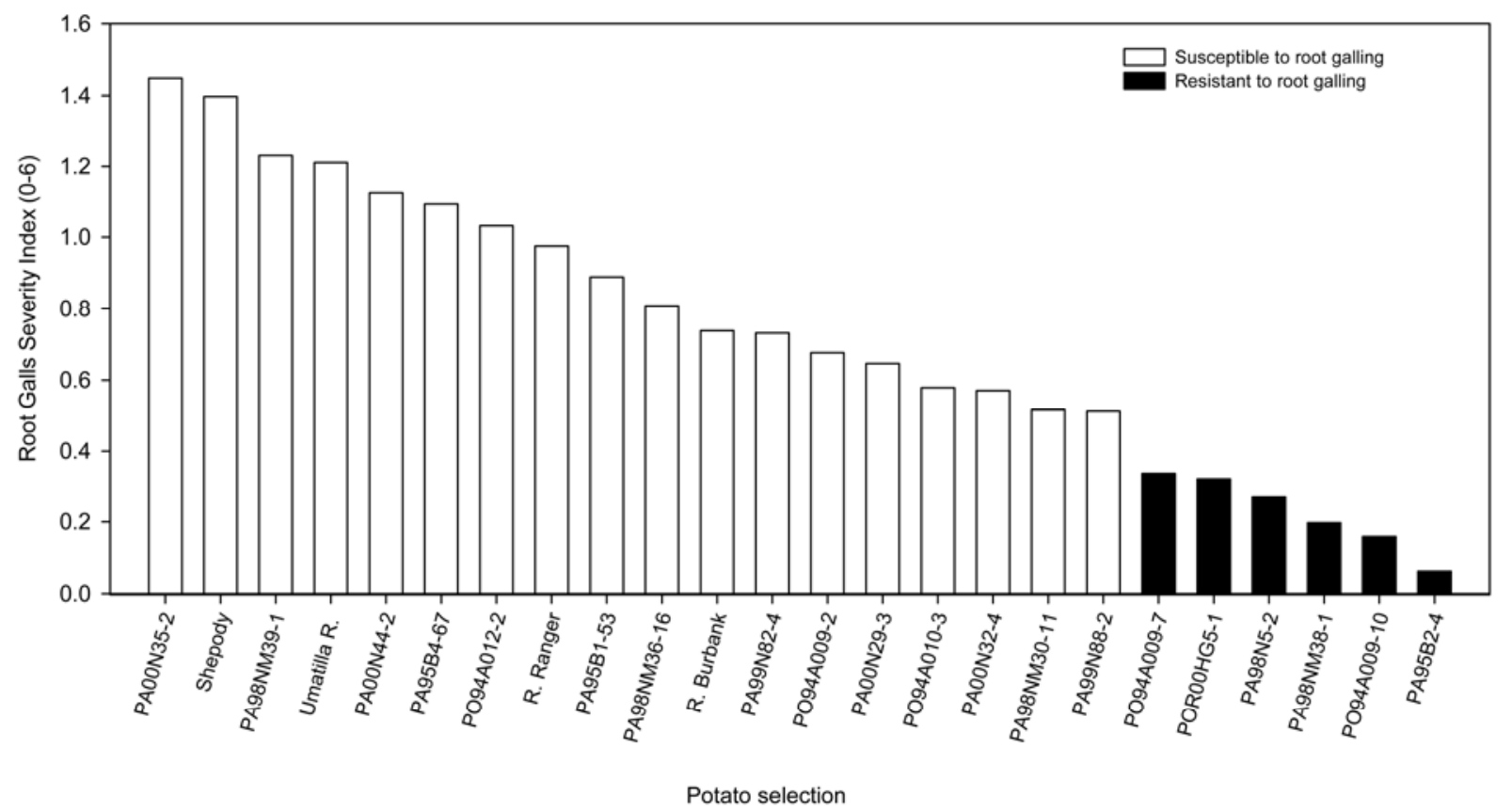

Fig. 2. The severity of galls on roots of potato selections tested for resistance to powdery scab in 2004 in a commercial field by Rexburg, ID. The commercial cultivars Shepody, Russet Burbank, Russet Ranger, and Umatilla Russet were used as susceptible standards. Selections represented by black bars were significantly more $(P<0.05)$ resistant to root galling than the susceptible standards using Fisher's least significant difference $(\alpha=0.05)$.

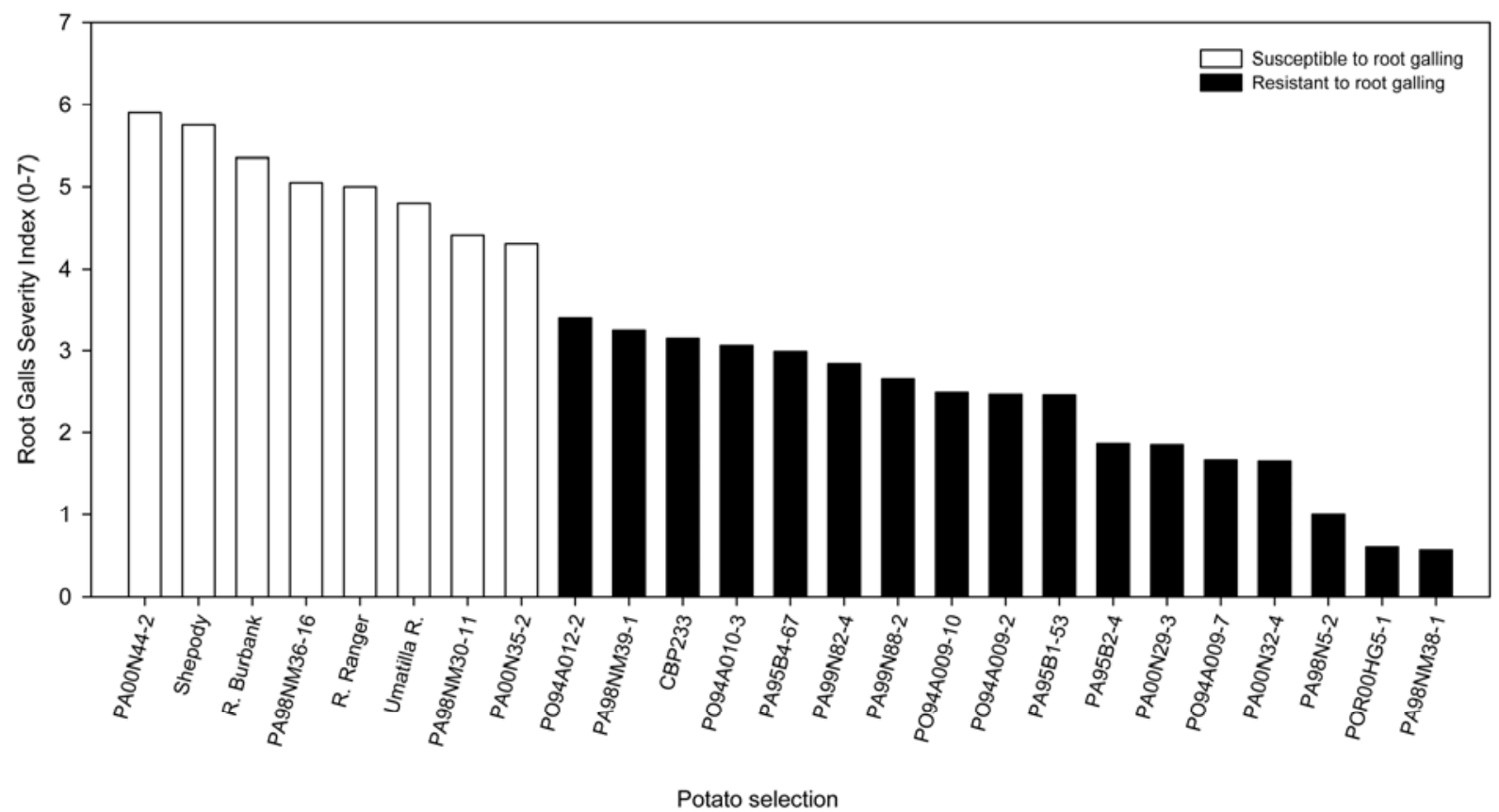

Fig. 3. The severity of galls on roots of potato selections tested for resistance to powdery scab in 2005 in a commercial field by Moses Lake, WA. The commercial cultivars Shepody, Russet Burbank, Russet Ranger, and Umatilla Russet were used as susceptible standards. Selections represented by black bars were significantly more $(P<0.05)$ resistant to root galling than the susceptible standards using Fisher's least significant difference $(\alpha=0.05)$. 
skin are no longer grown in areas of the Columbia Basin where populations of $S$. subterranea are high. These observations suggested that yields were sometimes reduced by 5 to 12 metric tons/ha (4). Furthermore, our observations indicate that the root galling phase may react with the black dot pathogen Colletotrichum coccodes to cause an additive yield reduction (D. A. Johnson, unpublished data). Consequently, the focus of the screening effort has been on identifying resistance to root galling.
To screen for resistance to root galling, the cultivars Shepody, Russet Burbank, Russet Ranger, and Umatilla Russet, which are important to the potato processing industry (22), were chosen as susceptible standards. These cultivars give a range of susceptibility from extremely susceptible like Shepody to medium susceptibility like Russet Ranger and Russet Burbank, therefore serving as a good baseline for selecting resistant and medium resistant potato germplasm. The cultivar Shepody, although extremely susceptible, was selected because it consistently demonstrated root galling in the field. In addition, its roots do not rot and decompose as early in the season as the roots of the other cultivars, allowing a more reliable indication of infection. The cultivar Russet Burbank was chosen because it is the most extensively grown cultivar in the region (22), and although susceptible on the roots, it is less susceptible than Shepody. These two cultivars gave a range of susceptibility levels (Table 2).

Scales for evaluation of field resistance to powdery scab are based on tuber dam-

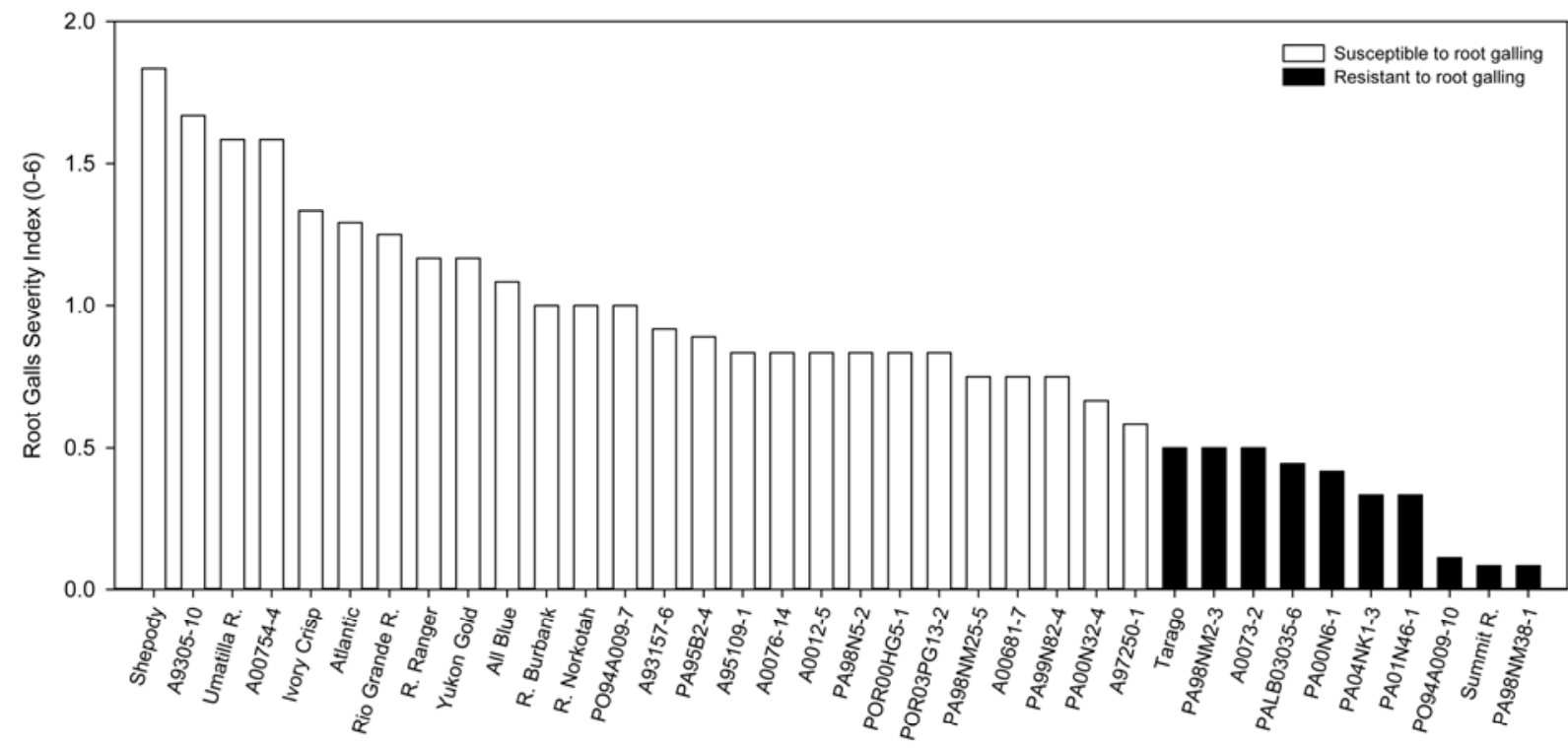

Potato selection

Fig. 4. The severity of galls on roots of potato selections tested for resistance to powdery scab in 2006 in a commercial field by Moses Lake, WA. The commercial cultivars Shepody, Russet Burbank, Russet Ranger, and Umatilla Russet were used as susceptible standards. Selections represented by black bars were significantly more $(P<0.05)$ resistant to root galling than the susceptible standards using Fisher's least significant difference $(\alpha=0.05)$.

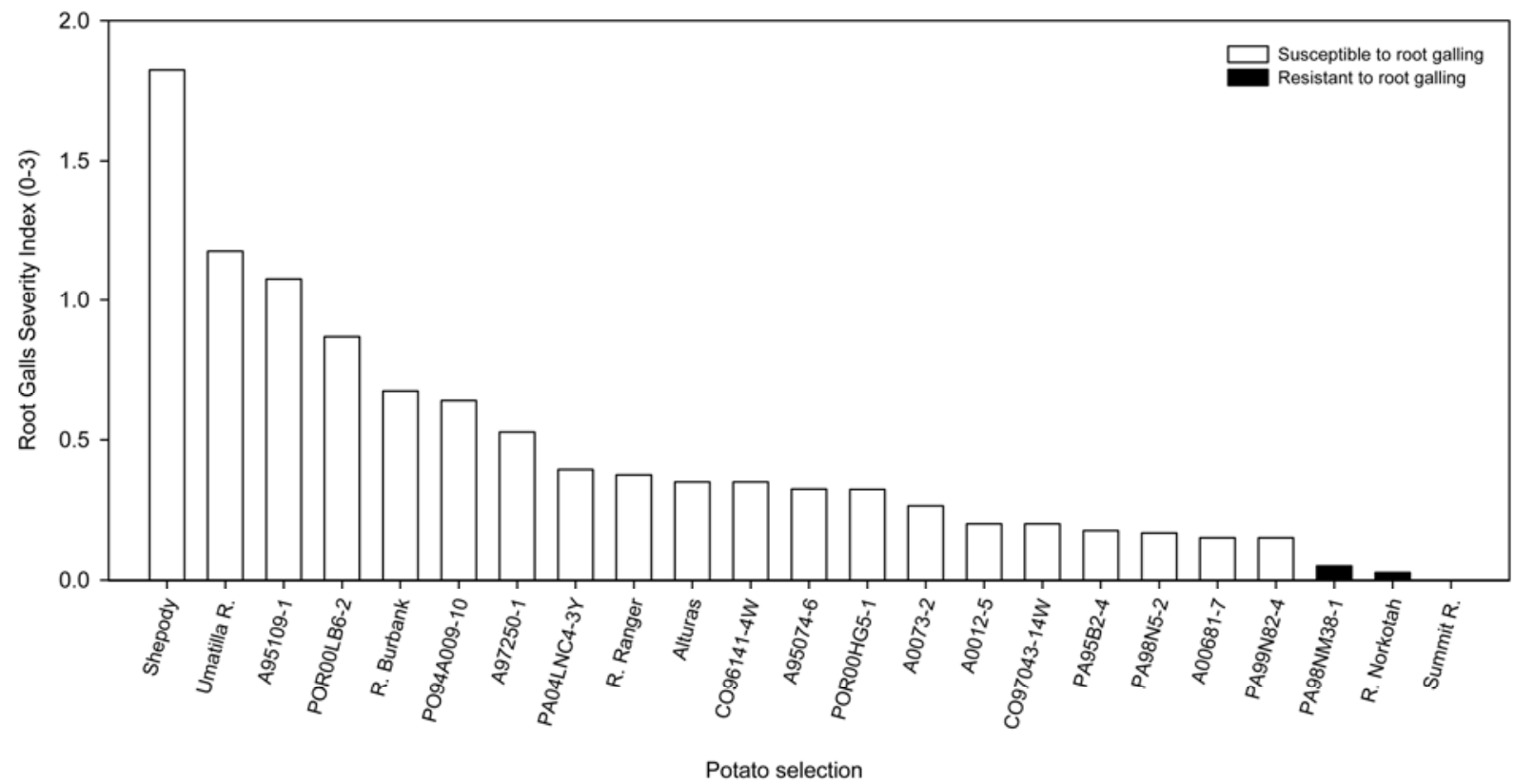

Fig. 5. The severity of galls on roots of potato selections tested for resistance to powdery scab in 2007 in a commercial field by Moses Lake, WA. The commercial cultivars Shepody, Russet Burbank, Russet Ranger, and Umatilla Russet were used as susceptible standards. Selections represented by black bars were significantly more $(P<0.05)$ resistant to root galling than the susceptible standards using Fisher's least significant difference $(\alpha=0.05)$. 
age $(8,18)$. Therefore, scales previously used in vitro and in greenhouse studies to score for root galling levels $(19,23)$ were adopted and modified for field purposes. The present research evaluated field trials by several investigators over a few years, and severity scales with different ranges were used. It was important that the scales be simple and allow rapid and repetitive scoring, since the evaluation was conducted in the field and in certain cases more than 300 plots were scored per day. Because the scales differed from year to year, each trial was analyzed individually using a nonparametric ranking analysis (29); and regardless of the scaling system, eight potato selections were consistently distinguished from the susceptible standards, indicating that either scale had merit. The scales used from 2004 to 2007 were similar in categories 0 to 4 , where: 0 $=0,1=1$ to 25 root galls, $2=26$ to $50,3=$ 51 to 100 , and $4=101$ to 150 . Our experience indicated that above 150 root galls, it became difficult to accurately assess the number of galls. Therefore, we suggest in future studies using a 0 to 5 scale, where: 0 $=0,1=1$ to $25,2=26$ to $50,3=51$ to $100,4=101$ to 150 , and $5=>150$.
The selections PA98NM38-1, PA95B24, PA98N5-2, PO94A009-10, PO94A0097, PO94A012-2, and the commercial cultivar Summit Russet demonstrated stable resistance in the field, and were significantly more resistant to root galling than the susceptible standards. Their pedigrees, presented in Table 4, indicate consanguinity among the selections, and have two factors in common: (i) all are derived from an introgression program to incorporate resistance to the Columbia root-knot nematode Meloidogyne chitwoodi from the Mexican wild species Solanum bulbocastanum; and (ii) all have the commercial cultivar Summit Russet appearing more than once in the ancestry $(3,4,17)$. Summit Russet is therefore the best explanation of the genetic source of resistance, and the origin of its resistance to powdery scab will be investigated in future research.

The identification of resistant potato selections is a promising step to sustainable management of powdery scab. Summit Russet, PA98NM38-1, PA95B2-4, PA98N5-2, PO94A009-7, and PO94A00910 have demonstrated a durable ability to limit root gall development over 4 years in five field trials and in two locations. These potato selections also have russet skin tubers that restrict lesion development. These traits would allow their use in fields with powdery scab history, while possibly limiting the reduction in tuber marketability. The selections' ability to restrict tuber lesions and root galling and therefore spore ball production could also potentially reduce $S$. subterranea inoculum levels in the soil, increasing profitability to growers over time.

S. subterranea can infect the roots of its hosts without the development of root galls or sporeballs (symptomless root infection). This phenomenon has been recorded on a wide range of hosts (21). Recently, Van de Graff et al. (23) reported that potato plants of the cultivar Estima, which were inoculated with a range of spore ball concentrations, were infected, but root galls did not develop. DNA of $S$. subterranea was detected in the roots of inoculated plants of Estima, suggesting infection by the pathogen. However, only 3 to $41 \%$ of the infected plants had root galls, while 31 to $72 \%$ did not. The study (23) may have detected in potato the mechanism present in other hosts that prevents the pathogen

Table 3. Resistance screening out-come and frequency of resistance of potato selections that were more resistant to root galling than the standard susceptible cultivars Russet Burbank, Russet Ranger, Umatilla Russet, and Shepody in two or more field trials conducted between 2004 and 2007 in the states of Washington or Idaho

\begin{tabular}{|c|c|c|c|c|c|c|}
\hline \multirow[b]{2}{*}{ Selection $^{y}$} & \multicolumn{5}{|c|}{ Field trials screening out-come ${ }^{x}$} & \multirow{2}{*}{$\begin{array}{l}\text { Frequency of } \\
\text { resistance }^{\mathrm{z}}\end{array}$} \\
\hline & 04-ID & 04-WA & 05-WA & 06-WA & 07-WA & \\
\hline PA98NM38-1 & $\mathrm{R}$ & $\mathrm{R}$ & $\mathrm{R}$ & $\mathrm{R}$ & $\mathrm{R}$ & $5 / 5$ \\
\hline PO94A009-10 & $\mathrm{R}$ & $\mathrm{R}$ & $\mathrm{R}$ & $\mathrm{R}$ & $\mathrm{S}$ & $4 / 5$ \\
\hline PA95B2-4 & $\mathrm{R}$ & $\mathrm{R}$ & $\mathrm{R}$ & $\mathrm{S}$ & $\mathrm{S}$ & $3 / 5$ \\
\hline PA98N5-2 & $\mathrm{R}$ & $\mathrm{R}$ & $\mathrm{R}$ & $\mathrm{S}$ & $\mathrm{S}$ & $3 / 5$ \\
\hline POR00HG5-1 & $\mathrm{R}$ & $\mathrm{S}$ & $\mathrm{R}$ & $\mathrm{S}$ & $\mathrm{S}$ & $2 / 5$ \\
\hline PO94A009-7 & $\mathrm{R}$ & $\mathrm{R}$ & $\mathrm{R}$ & $\mathrm{S}$ & $\mathrm{nt}$ & $3 / 4$ \\
\hline PO94A012-2 & $\mathrm{S}$ & $\mathrm{R}$ & $\mathrm{R}$ & $\mathrm{nt}$ & $\mathrm{nt}$ & $2 / 3$ \\
\hline Summit Russet & $\mathrm{nt}$ & nt & $\mathrm{nt}$ & $\mathrm{R}$ & $\mathrm{R}$ & $2 / 2$ \\
\hline Russet Burbank & $\mathrm{S}$ & $\mathrm{S}$ & $\mathrm{S}$ & $\mathrm{S}$ & $\mathrm{S}$ & \\
\hline Russet Ranger & $\mathrm{S}$ & $\mathrm{S}$ & $\mathrm{S}$ & $\mathrm{S}$ & $\mathrm{S}$ & \\
\hline Umatilla Russet & $\mathrm{S}$ & S & $S$ & $\mathrm{~S}$ & $\mathrm{~S}$ & \\
\hline Shepody & $\mathrm{S}$ & $\mathrm{S}$ & $\mathrm{S}$ & $\mathrm{S}$ & $\mathrm{S}$ & \\
\hline
\end{tabular}

x 04, 05, 06, 07 = 2004, 2005, 2006, and 2007; ID = Rexburg, ID; WA = Moses Lake, WA; R = resistant; S = susceptible; nt = not tested.

y Selections with greater $(P<0.05)$ resistance to root galling than the standard cultivars Russet Burbank, Russet Ranger, Umatilla Russet and Shepody in two or more trials.

${ }^{\mathrm{z}}$ The number of trials the selection had a greater $(P<0.05)$ resistance to root galling than the standard cultivars Russet Burbank, Russet Ranger, Umatilla Russet, and Shepody.

Table 4. Pedigree of potato selections that were tested twice or more in the field from 2004 to 2007 and were more resistant to powdery scab root galling than that susceptible standard cultivars Shepody, Russet Burbank, Umatilla Russet, and Russet Ranger ${ }^{\mathrm{z}}$

\begin{tabular}{ll}
\hline Potato selection & Pedigree \\
\hline PA95B2-4 & $((((S . b l b+\mathrm{R} 4) \times$ Summit Russet $)) \times$ Summit Russet $) .86 \times$ Lemhi Russet $) \times$ A8259-5 \\
PA98N5-2 & $((($ S. $b l b+$ R4 $) \times$ Summit Russet $)) \times$ Summit Russet $) .51 \times$ Ranger Russet $) \times$ A89875-5 \\
PA98NM38-1 & $(((S . b l b+$ R4 $) \times$ Summit Russet $)) \times$ Summit Russet $) 89 \times$ Lemhi Russet $) \times$ Summit Russet \\
PO94A009-10 & $(((S . b l b+$ R4 $) \times$ Summit Russet $)) \times$ Summit Russet $) .51 \times$ Ranger Russet \\
PO94A009-7 & $(((S . b l b+$ R4 $) \times$ Summit Russet $)) \times$ Summit Russet $) .51 \times$ Ranger Russet \\
PO94A012-2 & $((($ SB22 + R4 \{protoplast fusion\} $) \times$ Summit Russet $) \times$ Summit Russet $) \times$ Lemhi Russet $)$ \\
Summit Russet & A77236-6 $\times$ TND329-1Russ $(17)$ \\
\hline
\end{tabular}

${ }^{\mathrm{z}} \mathrm{S}$. blb $=$ Solanum bulbocastanum S. blb $+\mathrm{R} 4=$ Initial $\mathrm{F}_{1}$ was a somatic hybrid between SB22 and R4, a tetraploid $S$. tuberosum breeding line. Summit Russet (17), Lemhi Russet, and Ranger Russet are oblong russet skin varieties, and A8259-5 and A89875-5 are oblong shaped, russet skin breeding lines. These potato varieties were developed and named in the Northwest Tri-State potato breeding and variety development program, which is a collaborative effort of the USDA/ARS, Oregon State University, Washington State University, and University of Idaho, each state's potato commission and industry representatives, aimed to developing potatoes with agronomic, horticultural, and pathological traits suitable and sought for by the potato industry in the Northwest region. 
from root galling. If such a mechanism is present in potato, research evaluating the genes associated with restricting the pathogen from completing its life cycle needs to be determined. Real-time PCR techniques and histological approaches recording plasmodia or zoosporangia should be applied. The resistant selections identified in the present study could help assess the relationship between root infection and gall development.

In conclusion, the results of the present study established the baseline for further research on root galling of powdery scab and resistance screening. Eight resistant potato selections could be used as genetic parents in future crosses. Recommendations for future research are to apply the evaluation technique used with the four susceptible cultivars Shepody, Russet Burbank, Russet Ranger, and Umatilla Russet as susceptible standards, and with Russet Summit, PA98NM38-1, and P094A009-7 as resistant standards.

\section{ACKNOWLEDGMENTS}

We thank the Washington State Potato Commission for supporting this research. We thank Professor Marc Evans, Dept. of Statistics, Washington State University, Pullman, for his statistical assistance. We thank Ann Schneider and Shelli Welch for their technical support.

\section{LITERATURE CITED}

1. Alexopoulos, C. J., Mims, C. W., and Blackwell, M. 1996. Phylum Plasmodiophoromycota. Endoparasitic slime molds. Pages 751758 in: Introductory Mycology, 4th ed. John Wiley \& Sons, Inc., New York.

2. Bhattacharyya, S. K., Raj, S., and Dwivedi, R. 1985. Sources of resistance to powdery scab in potatoes. Indian Phytopathol. 38:174-175.

3. Brown, C. R., Mojtahedi, H., James, S., Novy, R. G., and Love, S. 2006. Development and evaluation of potato breeding lines with introgressed resistance to Columbia root-knot nematode (Meloidogyne chitwoodi). Am. J. Potato Res. 83:1-8.

4. Brown, C. R., Vandemark, G., Johnson, D., Cummings, T., Batchelor, D., Miller, J., and Olsen, C. 2007. Resistance to powdery scab in potato. Potato Progress 7(6):1. Published by the Washington State Potato Commission, www.potatoes.com

5. Diriwachter, G., and Parbery, D. G. 1991. Infection of potato by Spongospora subterranea. Mycol. Res. 95:762-764.

6. Dorojkin, N. A. 1936. Summary of seven years' investigation on powdery scab of potato, Spongospora subterranea (Wallr.) Johnson. Rev. Appl. Mycol. 16:273-274.

7. Eraslan, F., and Turhan, G. 1989. Studies on powdery scab of potato with special regard to the reaction of certain potato cultivars and clones. Z. Pflanzen-krankh. Pflanzenschutz 96:353-360.

8. Falloon, R. E., Viljanen-Rollinson, L. H., Coles, G. D., and Poff, J. D. 1995. Disease severity keys for powdery and downy mildews of pea, and powdery scab of potato. N.Z. J. Crop Hortic. Sci. 23:31-37.

9. Falloon, R. E., Wallace, A. R., Braithwaite, M., Genet, R. A., Nott, H. M., Fletcher, J. D., and Braam, W. F. 1996. Assessment of seed tuber, in-furrow, and foliar chemical treatments for control of powdery scab (Spongospora subterranea f.sp. subterranea) of potato. N.Z. J. Crop Hortic. Sci. 24:341-353.

10. Foister, C. E., Wilson, A. R., and Boyd, A. E. W. 1952. Dry rot disease of potato. Effect of commercial handling methods on the incidence of the disease. Ann. Appl. Biol. 39:2937.

11. Harrison, J. G., Searle, R. J., and Williams, N. A. 1997. Powdery scab of potato - a review. Plant Pathol. 46:1-25.

12. Johnson, D. A., and Cummings, T. F. 2004. Powdery scab: Is there a hope for economic control? Pages 25-26 in: Proc. 43rd Washington State annual potato conference. Published by the Washington State Potato Commission, www.potatoes.com

13. Johnson, D. A., and Miliczky, E. R. 1993. Distribution and development of black dot, Verticillium wilt, and powdery scab on Russet Burbank potatoes in Washington State. Plant Dis. 77:74-79.

14. Jones, R. A. C., and Harrison, B. D. 1969. The behaviour of potato mop top virus in soil, and evidence for its transmission by Spongospora subterranea (Wallr.) Lagerh. Ann. Appl. Biol. 63:1-17.

15. Kole, A. P. 1954. A contribution to the knowledge of Spongospora subterranea (Wallr.) Legerh., the cause of powdery scab of potatoes. Tijdschr Planten 60:1-65.

16. Lawrence, C. H., and McKenzie, A. R. 1981. Powdery scab. Pages 35-36 in: Compendium of Potato Diseases. W. J. Hooker, ed. American Phytopathological Society, St. Paul, MN

17. Love, S. L., Novy, R. G., Whitworth, J. L. Corsini, D. L., Pavek, J. J., Mosley, A. R. Thornton, R. E., Knowles, N. R., James, S. R., and Hane, D. C. 2005. Summit russet: A new russet potato variety with good fresh market and frozen processing qualities. Am. J. Potato Res. 82(6):425-432.

18. Merz, U. 2000. Powdery scab. Research in Switzerland. Pages 67-71 in: Proc. 1st Eur Powdery Scab Workshop. U. Merz and A. K. Lees, eds. SAC, Aberdeen, Scotland. ISBN 09 0587-516-8.

19. Merz, U., Martinez, V., and Schwarzel, R. 2004. The potential for the rapid screening of potato cultivars (Solanum tuberosum) for resistance to powdery scab (Spongospora subterranea) using a laboratory bioassay. Eur. J. Plant Pathol. 110:71-77.

20. Nitzan, N., Johnson, D., Batchelor, D., and Brown, C. 2007. Powdery Scab, An introduction to an important disease. Pages 6-7 in: Potato Country Magazine, July-August, 2007.

21. Qu, X., and Christ, B. J. 2006. The host range of Spongospora subterranea f.sp. subterranea in the United States. Am. J. Potato Res. 83:343-347.

22. Schreiber, A. 2006. Potato tuber-worm: A potential new pest of potato in Washington's storages. Potato Progress 6(13):3. Published by Washington State Potato Commission, www.potatoes.com

23. Van de Graaf, P., Wale, S J and Lees, A. K 2007. Factors affecting the incidence and severity of Spongospora subterranea infection and galling in potato roots. Plant Pathol. 56:1005-1013.

24. Wade, G. C. 1949. An unusual potato rot. J. Aust. Inst. Agric. Sci. 15:42-43.

25. Wale, S. J. 1987. Powdery scab - Are there any easy solutions? Potato World 4:8-9.

26. Wastie, R. L. 1991. Resistance to powdery scab of seedling progenies of Solanum tuberosum. Potato Res. 34:249-252.

27. Wastie, R. L., Caligari, P. D. S., and Wale, S. J. 1988. Assessing the resistance of potato to powdery scab (Spongospora subterranea (Wallr.) Lagerh.). Potato Res. 31:167-171

28. Whitehead, T., McIntosh, T. P., and Findlay, W. M. 1953. Diseases caused by Archimycetes, Actinomycetes and bacteria. Pages 367-403 in: The Potato In Health and Disease, 3rd ed. Oliver and Boyd, Edinburgh.

29. Zar, J. H. 1996. Biostatistical Analysis, 3rd ed. Prentice Hall, NJ. 